\title{
SOME REFLECTIONS ON CORSICAN SECRET SOCIETIES IN THE EARLY NINETEENTH CENTURY*
}

Stendhal, in La Chartreuse de Parme, described a minister of police who

"se garde bien de nier la conspiration, au contraire, seul avec le prince, et armé jusqu'aux dents, il visite tous les coins des appartements, regarde sous les lits et, en un mot, se livre à une foule d'actions ridicules dignes d'une vieille femme."

Thus it is when conspiracy is in the air, and such fears were not without parallel in the administrations of the European states in years between 1815 and 1848. The European cabinets in this "age of Metternich" were beset by a fear of revolution, international conspiracy, carbonari and illuminati, and a widespread suspicion of subversion. The picture of clandestine organisation whether drawn in Vienna, Paris, Berlin, Rome or Milan, was not vastly different nor entirely fictitious. The period was punctuated with armed revolts, coups, arrests of agitators, and the appearance of secret societies, often republican, dedicated to the overthrow of the existing order. It is not surprising that contemporaries and indeed some historians of the period exaggerated the links between these phenomena, even to the extent of occasionally suggesting that one principal organisation was at work with a series of national variants creating an international network. Revolt in Piedmont, Naples and Spain was readily conceived to have a connection with attempted coups elsewhere in Europe. Buonarroti, Mazzini, La Cecilia, Victor Cousin, General Lafayette and many others were observed by the police of Europe as they moved about the continent engaged on legitimate business and perhaps on work of a more subversive nature. The suspicion was constantly present that such men were the agents of international revolution. This was the case not least in the ranks of the French administration, where carbonarist activity came into prominence in $\mathbf{1 8 2 1}$ and 1822 and a fear of traffic in revolution remained until the middle of the century.

* The research for this article was undertaken with the assistance of the Nuffield Foundation and the University of Leicester. 
There is a large scholarship devoted to the account and analysis of these revolutionary projects, in particular to the carbonari and to the international secret societies of the nineteenth century. Yet among the details of the history of political subversion during these years there remains one area which has not been extensively examined and was not clarified at the time. The piece of revolutionary minutiae in question is the place of Corsica in the spreading of conspiracy and in the preparation of revolt. This essay, for such is really its nature, is concerned with this aspect of the secret political machinations, a subject for which there is minimal evidence and thus few firm conclusions can be drawn. Despite this inauspicious starting-point the role of Corsica does emphasise areas of social history which are not always associated with the study of secret political organisation, and stress the need to leave the centres of government and go to the localities in the pursuit of conspirators. The historian who does this may find, as is the case with Corsica, that the assumptions of the contemporary police were not well founded. Special local conditions affected the reality of conspiracy, and far from disclosing another link in an international network, one is led to shed further light on the Corsican situation of the early Nineteenth Century, particularly on the factional strife of the island and the pervasive influence of the clans. It was local issues which preoccupied the Corsican secret societies of this period, not international revolution, but this was not readily apparent at the time.

Corsica was still, in the early nineteenth century, a department which the French administration found difficult to control and perhaps understand. It was relatively a recent acquisition, and with strong ties both historical and geographical with Genoa, Tuscany and Sardinia, and the Italian peninsula generally, Corsica was a department with special problems. As fears and suspicions grew that conspirators were not always indigenous and that they moved across frontiers, the French governments of the Restoration looked increasingly at Corsica. What they knew of the recent past was not encouraging.

The island had changed hands during the Revolution. General Paoli had followed a rupture with the Convention in Paris by an appeal to his erstwhile hosts, the English. Corsica became subject to the English crown in 1794, with English troops and an English governor-general, Sir Gilbert Elliot. In 1796, while the French landed an expedition on one shore, the English moved out from another, and Corsica thereafter was restored as a French department (briefly in fact the island constituted two departments). However, constant fear of civil war remained together with the possibility of a further appeal to the English. 
In 1809 there occurred a "conspiracy of Ajaccio" supposedly with this intention. Riots and political disturbances bothered both the Bourbon Restorations and the return of Napoleon's administration in 1815. The English landed troops in 1814 and General Montresor was proclaimed "Gouverneur provisoire de la Corse" on behalf of His Majesty's Government. The municipal authority of Bastia was on the point of secession, encouraged by the presence of an English corvette in the harbour, in April 1814. The committee which took this action was finally obliged to capitulate and fled, mostly to Italy, to escape the return of the French. In another part of the island a band of some two hundred rebels, led by a former chef de bataillon, rampaged around the countryside, defying the Bourbon flag and talking of autonomy for Corsica. They even gained the support of the local community elders and raised taxes. ${ }^{1}$ Further proof that Corsica was fertile ground for any rebellion against the established order was provided by a serious revolt in 1816, known by the name of the river in the vicinity of which it occurred, the Fium'Orbo. This was a movement, led by the Commandant Bernard Poli, Napoleon's envoy from Elba in 1815, which required hundreds of troops, and several weeks to quell, and the region was quietened only by an amnesty and concessions. ${ }^{2}$ The French government could thus hardly credit the report from General Casabianca that "la Corse ne s'est pas révoltée contre la France. Les troubles [...] n'ont été l'ouvrage que d'une poignée d'hommes avides et ambitieux."3

This history of turmoil and the proximity to parts of Italy gave a special place to Corsica in the minds of those who sought conspirators, secret societies and the international ramifications of revolutionaries. The appearance of carbonari in Italy and elsewhere about 1820 prompted a closer look at Corsica by the French authorities. Inquiry revealed that Corsica had known carbonarism for many years, long before the Charbonnerie française organised a number of plots in France in 1821. The earliest references go back to 1814 and 1815. By 1819 the secret society appeared to have been thriving on the island. It was established by the police, and substantiated by historians, that Corsicans were implicated in the Charbonnerie when it was formed on the mainland. It was even revealed that a Corsican law student, from a distinguished family, Limperani de la Penta, had assisted in the formation of the Charbonnerie in Paris while studying there in the

1 Archives administratives de la Guerre, Vincennes (AAG), I 90.

2 See Mémoires du Commandant Poli, Archives Départementales de la Corse (AC), M 7(c), 96; also ibid., M 7, 114, and AAG, I 91.

3 This report referred to the events at Bastia but is typical of the over-confidence that was expressed by certain officials, AAG, I 90 . 
Spring of 1821 . He was a member of the principal cell of the organisation, the haute vente. ${ }^{1}$ Limperani was thought to have been a member of the carbonari in Corsica before 1821. The official investigation of the Ministry of the Interior showed that although reports of carbonarism came from several departments before the crucial years of the plots, 1821 and 1822, few reports were so regular and undisputed as those from Corsica where the first arrests had been made in $1819 .{ }^{2}$

The subversive influence of Corsica upon French political life seemed established by further evidence. Many Corsicans has been in Italy during the Empire, particularly in Naples. They had served in the forces of Murat, King of Naples, and with the Restoration in many cases they had returned to Corsica. It was thus possible to argue that carbonarism had entered France through Corsica, in the knapsacks as it were of such Corsicans who had been in Italy and become affiliated to the secret society there. The administration could name individuals who had been involved in such an experience. Among the Corsicans "rentrés du continent italien" was, for example, Doctor Risotini. He had been a member of the Neapolitan carbonari and returned to Corsica in 1814. Another was a former soldier, Raggi, also carbonaro in Naples, and Silvie Ottaviani, "fidèle et entièrement attaché à la famille Buonaparte", who returned in $1818 .^{3}$ Furthermore Murat himself passed through Corsica in 1815, accompanied by several officers of the Régiment Royal Corse who had been with him in Naples. His journey had a political purpose, to win support for his attempt to regain the throne of Naples. He travelled across the island in a manner "vraiment triomphale", "au milieu d'une cour quasi impériale". His motives however disturbed the French authorities: "Murat avait voulu que la Corse se déclarât indépendante, le choisit pour son protecteur. Il espérait employer les Corses à reconquérir le Royaume de Naples." He was disappointed in such hopes and left the island, spurned by his relatives in Ajaccio after some initial interest in him shown by some Corsicans in the interior. ${ }^{4}$ Nevertheless the Bourbon administration feared that contact with Murat and his henchmen might have resulted in the growth of a secret opposition in the department, and might have accounted for the existence of young conspirators like Limperani.

By 1819 carbonari were reported in all the towns of Corsica, and

1 A. Spitzer, Old hatreds and young hopes (Cambridge, Mass., 1971), pp. 231-232.

2 Archives Nationales (AN), F7, 6686. See especially the dossier relating to the Corsican suspect Joseph Guerini.

$3 \mathrm{AN}, \mathrm{BB} 30,241$. For Ottaviani, AC, M 7(4), 124.

4 The account of Murat's journey comes largely from the reports of the Prefect, $A C, M 7,113$. There is some further information in $A A G, I 91$, and in the Mémoires du Commandant Poli. 
from a large number of remoter villages. The same locations still reported carbonari in 1822, the year of carbonarist conspiracy in France. In the mainland departments reports of conspiratorial groups decrease after this peak, and the carbonari in particular faded as an active secret opposition until a revived form appeared after 1830 . The Corsican administration was obliged to draw a different picture. Secret groups of the carbonarist type seem to have had a more or less continuous existence through the Restoration and into the July Monarchy. Some records indicate a continuous activity by individual cells from the early part of the reign of Louis XVIII to the mid 1840s. Such seems to apply to the vente d'Alata. ${ }^{1}$ The optimism of a maréchal de camp writing in 1835 from Ajaccio, that "aujourd'hui le carbonarisme en Corse peut être considéré comme usé, anéanti" is scarcely justified. ${ }^{2}$ At that very time officers and men, stationed at Ajaccio, were being approached by carbonari, and Corsican troops in other parts of France were suspected of trying initiate their comrades into the carbonari. At Lyon many Corsicans of the 60th regiment of the line "appartiennent à la grande loge des B[ons] C[ousins] [i.e. carbonari] de Lyon". ${ }^{3}$ Evidence was continually produced during the July Monarchy of subversive activity and of "la propagande révolutionnaire qui se fait en Corse". 4

The Corsicans themselves were by no means the only people who attracted the attention of the French officials in Corsica and their superiors in Paris. The revolutionary propaganda came also from Italy and Italians could travel all too easily via Corsica. Communications were relatively easy, particularly between Livorno (Leghorn) and Bastia, as well as across the straits between Bonifacio and Sardinia. Genoa was as accessable as Toulon or Marseille. There was a regular flow of Italian workers crossing from the towns in the West of Italy to Corsica, and arrivals from Italy were observed throughout this period with care and suspicion. Shipping came under special scrutiny. The vessels run by a $M$. Valéry between Corsica and La Spezia at-

1 "La vente d'Alata", in: Le Petit Bastiais, 3 October 1934.

2 Report, 16 October 1835, 17me Division militaire, AAG, E5, 147.

3 These instances are taken from military reports, AAG, E5, 147, and the letter from de Castellane to the Minister of War, Perpignan, 21 September 1835, ibid. 4 Minister of War to the Minister of the Interior, Paris, 21 November 1835 , ibid. Etienne Cabet, "utopian socialist" and former member of the Charbonnerie française, was procureur du roi at Bastia in 1831, whence he reported activity among the secret groups there, J. Prudhommeaux, Icarie et son fondateur, Etienne Cabet (Paris, 1907), p. 4. Cabet was simultaneously suspected of fomenting trouble in Corsica by placing the Corsican carbonari "à la disposition des révolutionnaires italiens", Lt.-Général commanding $17 \mathrm{e}$ Division militaire to the Minister of War, Bastia, 23 November 1835, AAG, MR 2200. 
tracted attention. ${ }^{1}$ Another ship docking at Bastia in August 1820 was thought to have brought several carbonari from Italy. ${ }^{2} \mathrm{~A}$ few months later an armed vessel from Naples appeared in the gulf of SaintFlorent, flying the tricolore. The captain, Don Juan, came ashore and showed considerable interest in the fortifications of the town (not the women, despite the promise of his name). He questioned people in the streets concerning "l'esprit de la garnison, sur le nombre des officiers corses qui avaient été au service de Naples et qu'il a tenu ensuite des propos révolutionnaires". ${ }^{3} \mathrm{He}$ departed finally for Antibes or Marseille. Such arrivals were bound to worry the local sous-preffets and the Ministry of the Interior maintained an interest in these comings and goings. But their attention concentrated especially upon those Italians who came to stay in the island.

There were many Italians resident in Corsica in the early part of the nineteenth century and among them the political exiles from the Italian states were suspected of fomenting trouble. Their activities in Corsica were closely supervised. ${ }^{4} \mathrm{La}$ Cecilia, involved in the revolutionary events of 1821 and 1831 in Tuscany and Piedmont, was suspected of covering his revolutionary preparations in Corsica where he had exiled himself, by a company "pour l'exploitation des bois de la Corse". ${ }^{5}$ No conclusive evidence of a conspiracy was produced, and during this period the island seems to have been used principally as "le dépôt de les [sic] écrits clandestins". At the same time it was feared that the influence of the exiles might have harmful results. In 1829 they were responsible for the creation of a carbonarist cell in Bastia. In 1847 they were accused of trying to take over another secret society for the purposes of carrying revolt to Italy: "c'est particulièrement sur les membres de la société secrète dite des Pinnuti dont le siège est dans les arrondissements de Bastia et de Corte [most easily reached from the East coast] que l'on emploierait les moyens de séduction."6

$1 \mathrm{AC}, \mathrm{M} 7,132$.

2 Commissaire de police, Bastia, to the Prefect, 11 August 1820, AC, M 7, 39.

3 Sous-préfet, Bastia, to the Prefect, 5 March 1821, AC, M 7, 39.

4 Their numbers varied but some indication of the size of this population can be gained from the petitions for aid and the individual dossiers in the Archives Départementales, M 7, 132 and 135. For example, these show that there were about thirty Italian exiles from the papal states at Bastia in 1828 and 1831 . In December 1851 there were 59 Italian political exiles resident in Bastia. Cf. Sous-préfet, Bastia, to the Prefect, 2 August 1828, AC, M 7, 39.

5 Minister of the Interior to the Prefect, 25 October 1845, AC, M 7, 298, dossier La Cecilia.

6 This quotation, and the previous, from an official report, 5 August 1847, AC, M 7, 298. Cf. "Les Pinnuti ont remplacé les carbonari; l'une et l'autre de ces associations secrètes ont une origine italienne", quoted by $\mathrm{A}$. Pasqualini and 
Italians throughout the July Monarchy were prominent among the members of the Corsican carbonari and the pinnuti. There was thus much speculation about the response of the Corsicans to their behaviour. Would the islanders join the schemes of the Italians, with the intention of sending an expedition to Italy, or of preparing an insurrection against the administration in Corsica? Major expeditions were rumoured for 1835 and 1838.1 The pessimists stressed the links between Italy and Corsica: "les communications entre la Corse et l'Italie sont journalières. Les habitants considèrent les Italiens comme leurs compatriotes." 2 A joint action by the Corsicans and the Italians was thus not excluded. In February 1844 the Prefect was warned by his Minister that

"les propagandistes italiens cherchent les occasions de tenter un mouvement révolutionnaire dans les Etats Pontificaux. Votre département est signalè comme le foyer principal où s'organiseraient les moyens d'attaque; on va même jusqu'à parler d'un débarquement à opérer sur les côtes d'Italie, et l'on ajoute que, dans la Corse, quatre mille hommes ont offert leurs services et se tiennent prêts à favoriser une descente."3

The sous-préfet at Sartène, in the interior of the Southern part of Corsica, noted that "mes administrés, comme les autres habitants de la Corse, éprouvent pour la Corse italienne une vive sympathie". ${ }^{4} \mathrm{He}$ added that a successful revolution by the Italians could result in many Corsicans going to join them. He did not explain whether he thought that a serious attempt would also be made to prize the island away from France.

The fears of the pessimists were not well founded, however, and little positive evidence of subversion came to light. It seems that the Prefect, Jourdan du Var, almost fifteen years in Corsica, was perhaps correct when he claimed that the islanders were unlikely to be seduced by the propagandists; they were, in general, "réfléchis", "sérieux" and "moins faciles à égarer". ${ }^{5}$ But such assurances did not satisfy Paris, and Corsica remained an object of mistrust with sufficient evidence of carbonarism and unrest to keep such suspicion alive.

L. Olivieri, I Pinnuti e la Corsica nel 1848 (Livorno, 1929), p. 5. Cf. E. Michel, Esuli italiani in Corsica, 1815-1861. (Bologna, 1938).

1 M. A. D. Pietriccioli, "L'irrédentisme en Corse", in: Revue des Etudes Corses, January-March 1961, p. 16.

${ }_{2}$ Minister of the Interior to the Prefect, quoting the French consul in Rome, Paris, 17 September 1851, AC, M 7, 132.

3 Minister of the Interior, Paris, 24 February 1844, AC, M 7, 132.

48 October 1847, AC, M 7, 298.

5 To the Minister of the Interior, 7 March 1844 , AC, M 7, 132. 
What concerns me in this article is less the disentangling of the skein of revolutionary activity in the Europe of Metternich, than the nature of the secret society in a particular locality, and to ask whether the purpose of subversive political association was to serve Corsican rather than international ends. My researches lead to the belief that such activity, for carbonarism was only one of the secret societies, was indeed closely connected with the local problems and needs.

Coordination between conspirators in Corsica and the rest of France seems to have been minimal, if there was any at all. Whatever occurred in the matter of conspiracy in the other French departments had no apparent connection with anything which took place on the island. There is a notable lack of evidence for the coordination of preparations at those times when plots were being hatched on the mainland, for example in 1822. The apparatus of carbonarist conspiracy seems even to have been missing, the dépôts d'armes, the revolutionary committees, plans to capture key-points, tightly structured cells. This is in clear contrast to the evidence from many other departments for the same period. Carbonarist action seems to have been limited to isolated killings and fracas. At Cervione for example, in 1828, about twenty carbonari arrived from a nearby village, Santa Maria Poggio, and fought with a number of other young men. ${ }^{1}$ Here is an episode of quite a different nature from the conspiracy of La Rochelle, for which the Four Sergeants lost their lives, or that of Belfort, or of May, 1839. There was no Corsican counterpart to such events; despite the history of turbulent politics, these decades were apparently less disturbed by political violence of this kind than in many other departments. The secret societies existed certainly, but their operations were not dependent upon the dictates of Paris, Rome, Milan or other centres of revolutionary activity. In Corsica the role of the secret societies seems to have been decisively local, helping to perpetuate local rivalries and the exercise of influence within the department. To assert this is to bear in mind the special character of Corsican politics.

Political life in Corsica was dominated by the family. This was still true of the nineteenth century, where the strength of the patttern of family ties provided this department with an example of a clan structure of the purest and most active kind. The clan rivalry was scarcely unique but was found there in an extreme form. There was no question of the dominance of a small group of notables, based upon large estates. Such feudalism had disappeared long before. What had replaced it was a network of families with their extensive clientele. It

1 Bonaldi, self-styled conseiller d'arrondissement, to the sous-préfet at Bastia, Saint-Lucia, 9 February 1829, AC, M 7, 39. 
was not that the department was divided neatly into two camps, for the administration and against, Sébastiani opposing Pozzo di Borgo, but rather a complex interlacing of relationships competing for prestige, influence and position in each commune, village and glen. The families were extended, with relatives by marriage carrying their influence beyond a single commune into the farther parts of the island. The family of Buttafuoco, for example, closely associated with the French and yet unquestionably Corsican, were related to the Giubega in the Calvi region, the Antoni at Bastia, the Casalta d'Ampugnani, the Morelli (themselves related to the Gaffori, heroes of the Wars of Independence in the mid-eighteenth century), the Boccheciampe d'Oletta, the Monti de Palasca. ${ }^{1}$ The family retained its loyalty to the capo di partito, in whom the nucleus of the family was indeed embodied and to whom even the more remote members would feel some loyalty. The strength of this loyalty was emphasised by the persistence of such traditional forms as the vendetta, the most important Corsican survival of earlier feudalism in which the prestige and position of the family and the capo di partito were protected and avenged through several generations and degrees of parentage if necessary. A corollary of this was one form of banditry, to take to the maquis; this necessity was imposed upon a member of a family pursuing his vendetta, and simultaneously pursued by the authority of the law for killing in defence of his family's honour. The bandit must thus be carefully distinguished from the brigand, little better than a petty thief, and seen, in principle, as concerned with affairs of honour. ${ }^{2}$ However, in the context of secret opposition, it is the political consequences of the clan structure which are important.

A major consequence of the clan structure was the existence of an "esprit de parti", "une volonté primordiale d'affermir leur influence, leur prestige". ${ }^{3}$ It was not simply that elections afforded an opportunity for the clash of rival families and their clienteles, but all forms of political activity were coloured by this competition. Officials were especially important, and among them the mayor held the most important place. He was responsible for the organisation of elections, the allocation of rooms in the villages for meetings, the distribution of communal land for grazing, he supervised the tax returns and had control over the surrounding countryside. The electoral lists "sont souvent formées par le parti qui possède le pouvoir, dont les principaux membres composent le conseil municipal, et à la tête duquel est le

1 F. Pomponi, "Sentiment révolutionnaire et esprit de parti", in: Annales Historiques de la Révolution Française, XLIII (1971), p. 68.

$2 \mathrm{X}$. Versini, Un siècle de banditisme en Corse 1814-1914 (Paris, 1964), p. 43.

3 F. Pomponi, loc. cit., p. 65. 
maire qui propose les répartiteurs". ${ }^{1}$ A similar situation applied to the administration of justice in the early nineteenth century, when "tout Corse se rattache à un parti". "C'est grâce au parti que le juge a été nommé, c'est lui qui va pourvoir à son avancement, c'est par lui qu'on l'atteindra."2 Office and advantage were the objectives of clan rivalry, and, in the words of a report compiled for the Convention in 1793 by Volney, "les effets de ce système ont été de concentrer les places et les traitements dans les mains de quelques chefs et de leur parenté".

Two consequences followed from this situation. In the first place all issues tended to be translated into terms of clan rivalries. Loyalties tended to be clan loyalties and not directed towards abstract ideas as such or towards policies. The clan was an association of interests, concerned with the satisfaction of those immediate interests and not devoted to a principle, held regardless of circumstance. Although there were some issues which did divide Corsicans on lines other than those of clan and clientele, for example the question of religion during the French Revolution, or the towns against the country villages over questions of land possession and proof of ownership, it was these considerations of clientele which predominated. ${ }^{4}$ The second consequence was that any novel form of political organisation to appear in the island was readily and inevitably incorporated into the politics of the parti, and this was precisely the fate of the secret political societies of the $1820 \mathrm{~s}$ and $1830 \mathrm{~s}$. The ventes of the carbonari thus quickly became involved in the struggle between clans, and although incontrovertible evidence does not exist there are a number of interesting pointers.

As with secret societies elsewhere many levels of society were represented in the groups in Corsica. But on the island there were remarkable numbers of notable and locally important people affiliated to the carbonari particularly. Their presence was remarked by the contemporary administration. The juge de paix of Casinca could list several mayors and members of distinguished families among the local

1 Prefect's report to the Conseil Général, Ajaccio, 1846. Cf. the observation of the Juge de Paix at Cervione to the Procureur at Bastia, 24 November 1871, regarding the parties: "le seul but est de se disputer le pouvoir c'est-à-dire la mairie", AC, I M 7, 56.

2 X. Versini, op. cit., p. 86.

3 "Précis de l'état actuel de la Corse", in: Le Moniteur, 20 March 1793.

* See Paul Bourde, En Corse. L'Esprit du clan. Les mœurs politiques. Les vendettas. Le banditisme (Paris, 1887), passim; cf. F. Pomponi, loc. cit., pp. 65ff., and A. J. Tudesq, Les grands notables en France, 1840-1849 (Paris, 1964), I, p. 115, who notes that the notables "ont une influence solide [. . . chefs de clan indifférents aux problèmes nationaux". 
carbonari. ${ }^{1}$ In the period 1815-1840 the following well known Corsican families included carbonari or suspected members of the society Abbatucci, Bonaparte, Casabianca, Colonna d'Istria, Durazzo, Grimaldi, Limperani, Mattei, Ortoli, Pietri, Poli, Pozzo di Borgo and Sébastiani. The precise extent of their commitment is not known. Perhaps they were no more involved than those Liberal deputies whose names were exploited by the Charbonnerie française in 1822 . Another juge de paix, at Saint-Nicolas, summed up the position thus: "ils ont leurs chefs [...] ils se disent hautement protégés". ${ }^{2}$

The Corsican carbonari seem to have been characterised by vague aims, perhaps more so than in other parts of France. In some instances a welfare aspect was prominent. Articles of association discovered among carbonari at Calenzana have as the first "de se prêter en toute occasion un mutuel secours". The members ensured that "les plus besogneux reçoivent 30f. par mois du caissier". ${ }^{3}$ This type of provision was by no means unknown elsewhere but rarely appears so strongly in the regulations of the society. In Italy and in other departments of France the republican objectives of the carbonari are given much weight. Some Corsican groups also shared this political aim, as did those at Saint-Nicolas and those apprehended by the police in 1819 and led by Joseph Guerini. ${ }^{4}$ But given the number of references to carbonarism in Corsica there were few clear-cut claims to republicanism. More common were reports like that made by Charles Moretti, suspected and arrested at Bastia, who was simply opposed to "le gouvernement et religion actuels". ${ }^{5}$ Bonapartism was more prevalent in the first years of the Restoration when many of the avowed influences came from Naples and Murat; thus Ottaviani was "entièrement attaché à la famille Buonaparte". The Minister of the Interior made an apparently fair assessment in 1822, in stating to the Prefect that "c'est avec raison que vous n'isolez pas les manœuvres des carbonari des intrigues qui se rattachent aux partisans du régime impérial". ${ }^{6}$

The key point would seem to be that made by the writer of an article which appeared in Le Petit Bastiais on 12th March 1937: "en

1 To the procureur du Roi at Bastia, 14 October 1822, AN, BB 30, 241.

2 To the procureur général, 19 February 1829, AC, M 7 (4), 120. Cf. "On sait que les 'carbonari' corses - devenus les 'Pinnuti' - appartiennent pour la plupart à des familles notables." $\mathrm{H}$. Yves-Croce, "Panorama de la presse corse aux 18me. et 19me. siècles, 1762-1852", in : Revue Corse Historique, No 23-24 (1966), p. 56, note 1.

3 Report from sous-préfet at Calvi to the Prefect, 25 April 1834, AC, M 7, 39.

4 For Saint-Nicolas see juge de paix to procureur général, 19 February 1829, AC, M 7(4), 120. For Guerini, see AN, F7, 6686.

54 November 1822, AN, BB 30, 241.

- To the Prefect, AC, M 7(4), 120. 
bref, par son caractère confidentiel, la vente constituait alors la seule possibilité à une opposition aux dirigeants locaux." During the reign of Charles $\mathrm{X}$, this writer claims, many carbonari were Orléanist thus enabling them to pursue a conflict with families who had adopted a Bourbon label. Such an opposition could be found in other ventes in Corsica. At Alata, for example, the vente was Bonapartist partly in order to group the local rivals to the Pozzo di Borgo, great opponents of the Bonaparte family in this area near Ajaccio. The vente was "composée des adversaires locaux des Bozzo di Borgo, ayant d'ailleurs à sa tête - grand-maître - un Pozzo di Borgo dissident, officier de l'Empire et demi-solde". ${ }^{1}$ Furthermore the carbonari were not an isolated secret society, but their presence frequently coincided with that of other secret groups. Several communes were plagued with carbonari and fischiolini. The latter were regarded, by the former, as "espions du roi et du gouvernement". The fischiolini were thus royalists; "Son but, d'empêcher, de ce que je viens d'apprendre, les rapides progrès de la faction des carbonari". ${ }^{2}$ It is likely that local interests explain this opposition as much as the political principles displayed by each group. A colonel of the gendarmerie at Bastia, basing his judgement on the report of the local gendarmerie at Cervione, was sceptical of the sincerity of the royalist sentiments of the fischiolini. He suggested to the Prefect that it was a matter of a gathering of rival groups of "jeunes gens". ${ }^{3}$ We know that wherever large groups of fischiolini were reported, there were also carbonari, as at Cervione, Calenzana, Saint-Nicolas, Santa Lucia and Santa Maria Poggio. Thus when twenty carbonari from Santa Maria Poggio descended upon Cervione and fought with members of an association there, this is less an act in an international revolutionary drama, than the enactment of a local feud. We are very far from Buonarroti and conspiracy to overthrow the Bourbons. Unfortunately the details of such minor confrontations are not fully recorded, but the general point seems clear; the secret societies become interesting not only for their own sake but as part of local, in this case Corsican, history.

This is emphasised by the major difference between secret opposition in Corsica and that of other departments, that is to say, the continuity of such groups on the island. The persistence of secret societies reflected the problems of administration and the violent "style" of local political

1 Le Petit Bastiais, 3 October 1934.

2 Bonaldi, conseiller, to the sous-préfet at Bastia, Saint-Lucia, 9 February 1829, AC, M 7, 39. Over one hundred fischiolini attended one meeting at SaintNicolas in 1829, Juge de paix, Saint-Nicolas, to the procureur-général, 19 February 1829, AC, M 7(4), 120.

314 February 1829, AC, M 7(4), 120. 
behaviour. It was precisely the difficulty of scrutiny by the government officials which enabled the groups to survive for so long. They flourished above all in the remoter areas, whether carbonari, fischiolini, pinnuti or the association of La Marianna which lasted from the 1840s into the Second Empire. ${ }^{1}$ The groups were most frequently reported, not from Ajaccio and Bastia, the largest towns on the island, nor even from Bonifacio and Saint-Florent, ports of less significance although more used in the days of sail. The most frequent reports came from the then pestilential East coast region, the foothills and valleys that run down to that coast, from the Nebbio, a remote and hilly region in the North, and from the wild mountains between Sartène and PortoVecchio in the central South. Administration was difficult in these regions. Communications were slow and irregular, until the Second Empire when roads were extended and the reports of secret associations began to decline considerably. In 1846 only 57 out of 354 communes could be reached by means other than on foot, on horse-back or mule, from Ajaccio, Bastia or the other capitals of the arrondissements. ${ }^{2}$ The mayors and the local families controlled these villages in a very real sense. Resort to external justice and redress from the authorities of the French administration was difficult or impossible, as is witnessed by the numerous dossiers of complaint lodged in the Archives Départementales. In such remote areas traditional forms of law and execution were slow to be replaced - "chez eux l'ardeur de la vengeance n'est que la soif de la justice". 3

The French struggled for years against the vendetta and the feud, against the carrying of arms and against the abuses of the jury system, periodically suspended, and of course against banditry. The constant demand from these regions was for more agents of the central government, more police, more troops, more gendarmes. Those that were available were often resented and their authority flouted. The experience of the gendarmerie of Calenzana, in April 1834, was not exceptional: in that case, "ayant arrêté un individu qui se trouve sous mandat de justice et appartenant à la société des carbonari, une rébellion contre la force publique s'en est suivie". 4 The result was the escape of the arrested man and several injuries sustained by the gendarmes who retreated. The conclusion, echoed by many administrative officials in Corsica, was clear to the sous-préfet who reported the incident: "Cet arrondissement manque d'une force suffisante pour

1 For the later secret societies see AC, M 7, 26.

2 Conseil Général de la Corse, 1846.

3 Un solitaire, La Corse depuis le premier Empire jusqu'à nos jours (Paris, 1861), p. 32, note 1 .

4 Sous-préfet, Calvi, to the Prefect, 25 April 1834, AC, M 7, 39. 
y maintenir la tranquillité." The Prefect announced to the departmental Conseil Général in 1850 that "Malheureusement, l'action de l'autorité préfectorale est fort restreinte. [...] dans plusieurs communes la police rurale a complètement disparu."

The temptation to believe the worst, to believe that an international conspiracy was actually organised was too often the resort of the government in Paris when confronted with reports from Corsica. It was so easy to give relatively minor incidents an importance which they did not rightly possess. This applied to the most extreme case of actual violence to occur during the period, the revolt of the Fium'Orbo of 1816, which typifies this whole point. The revolt was at once regarded as a Bonapartist plot. There were a number of former Imperial Officers involved, Poli, Colombani, Ortoli, but the Bonapartist element was competing for favour among the rebels and their supporters with two strong local grievances, the demands for the payment of arrears of taxes and the refusal of these mountain people to submit to the French officials. In addition the inhabitants of the three communes most closely involved, Prunelli-di-Fiumorbo, Ornaso and Isolaccio-diFiumorbo, demanded the integration of the village of Migliacciano with their communes - this village lay on the coast road and commanded the route from the three communes to Bastia and Bonifacio. However, to the Marquis de Rivière who first tackled the revolt and in effect failed to stop it, the proof of treason was the raising of the tricolore and his attention was diverted from the demands of the villagers. The sous-preffet of Bastia was nearer the mark by observing that "dans beaucoup de communes, le peuple est mécontent vu que les percepteurs, pour faire crier le peuple, leur font payer des contributions arriérées, lesquelles beaucoup ont payé et n'ont point conservé les reçus". ${ }^{1}$ Moreover these communes belonged to a region which " $n$ 'a jamais été qu'imparfaitement soumis", and was a refuge "des voleurs et des assassins". ${ }^{2}$ The key to this insurrection lay in the local stituation and it was quelled by answering the local grievances. A similar tendency to exaggerate greeted the reports of secret societies. The local circumstances surrounding their formation disappeared amid the misty notions of international conspiracy. The context of violence and of the secret society was likely to be different here from Paris, where conspirators did plot to overthrow the regime.

What conclusions can be drawn from the tentative exploration into a backwater of conspiracy and secret political association? It is clear

1 To the Prefect, undated, AC, M 7, 114.

2 Prefect to the Minister of the Interior, Ajaccio, 29 April 1816, AAG, I 91. 
that Corsica was not a transit camp for revolutionaries coming from Italy on their way to Paris, participating in a European movement. There were a few such persons who briefly stayed on the island, Mazzini among them. Several Italians undoubtedly wished to see Corsica as a spearhead for a landing on the Italian peninsula, and even to integrate Corsica with Italy. Mussolini was to revive these last schemes, but the Corsicans of the 1830 s and $1840 \mathrm{~s}$, as those of the 1930s and 1940s, had little time for such projects. Despite anxiety in Paris caused by events in Italy throughout the first half of the nineteenth century, no direct and strong links were forged between Corsica and an international conspiracy or society.

The most important conclusion is really one of emphasis. The example of Corsica stresses the necessity of seeing violence and the secret society in its local context. The role of the carbonaro was transformed by the relationships of rural politics. He was not primarily an international or even national revolutionary, but was shaping the political future of a remote and rural department involved in the "lutte de clan contre clan". ${ }^{1}$ This is the difference which helps to explain the particular experience of Corsica and its secret societies, their persistence, and the vagueness of their political aims, and their relative inertia when it came to insurrection. The plots and revolutions took place elsewhere.

Le Petit Bastiais, 14 August 1935. 